\title{
RISK MANAGEMENT IN AGRICULTURE UNDER CLIMATE CHANGES
}

\author{
Vladimir Njegomir, ${ }^{1}$ Rajko Tepavac, ${ }^{2}$ and Tamara Bikicki ${ }^{3}$
}

\begin{abstract}
Summary
Agricultural production is exposed to the effects of various risks, of which the production risks represent its specificity, given that they stem from the fact that the production is done outdoor and that it encompass management of living beings. Climate changes directly affect the production risks of agricultural production. In the literature, climate change are relatively sufficient researched but there are scarce studies that deal with the theme of risk management in agricultural production and in particular the management of risks under climate changse. With this in mind as the goal of the paper we have determined the need to point out on the importance and forms of agricultural risk management under climate changes. In an effort to achieve the goal, in the paper we first point out to the basic characteristics of agricultural production risk management and then we point to the application of preventive measures, the role of the state as well as the comparative role of insurance. As the impact of climate changes have strongly negative impact on insurance companies that provide insurance for agricultural risks, we consider the issue of wheatther the conclusion of agricultural insurance contracts should be mandatory or voluntary.
\end{abstract}

Keywords: agriculture, risks, management, prevention, state, insurance.

JEL: $Q 01, G 22$.

\section{Introduction}

The development of civilization was followed by risk, from the original communities to the present day, making an integral part of all human living and working activities. Although the existence of risk has always been in conflict with man's aspirations, we can consider that the

1 Vladimir Njegomir Ph.D., Associate Professor, Faculty of Law and Business Studies Dr Lazar Vrkatić, Bulevar oslobođenja no. 76, Novi Sad, 21000 Novi Sad, Phone: +381 64 13930 05, E-mail: vnjegomir@eunet.rs

2 Rajko Tepavac Ph.D., Associate Professor, Institute for economics and finance, Bulevar Mihajla Pupina no. 10 B/I, 11000 Belgrade, Serbia, Phone: +381 63600 217, E-mail: tepavac57@gmail.com

3 Tamara Bikicki M.Sc., Triglav osiguranje, Milutina Milankovića no. 7a, 11000 Belgrade, Serbia, Phone: +381 6388785 14, E-mail: tamarabikicki@gmail.com

EP 2016 (63) 4 (1403-1416) 
whole progress of civilization, without the existence of risk, would be absent or considerably slower. For example, in the agricultural production it would be avoided the development of irrigation system, hybrid varieties of crops, herbicides and pesticides. Technical and technological development has enabled the achievement of higher yields, which is shown in studies of genetically modified organism impact in developed and developing countries (Snow et al., 2005), but it caused the occurrence of uncertainty about the long-term impact on the environment and human health.

Agricultural production is exposed to numerous risks which has created a number of different classifications of risk. OECD (2000) distinguishes risks that are similar to all businesses and the risks specific to agriculture, which includes manufacturing, environmental, market and regulatory risks. For cops and fruits in the literature are most often considered weather conditions an prices of inputs and outputs while in the livestock usually considered risk is risk of disease (Gramig et al., 2006, Shaik et al., 2006). The most appropriate division of agricultural risk is: 1) regulatory or institutional, 2) market or price risk and 3) production risk (Pejanović, Njegomir, 2011). Regulatory risk arises from potential changes in agricultural policies and regulations while price risk stems from price fluctuations of inputs and outputs of agricultural production (Pejanović, Njegomir, 2011). Production risks arise from the fact that agricultural production is realized in the open and is based on the management of living organisms, plants and animals, and it depends on weather conditions, pests and diseases.

Global climate change has direct influence on the increase in catastrophic events such as hurricanes and winter storms and also has numerous other effects, such as impacts on the availability of food, habitation, human health, ecosystems and water resources. Climate changes directly affect the increase of production risks in agricultural production.

In the literature, there is a relatively large number of papers dealing with the implications of climate change. However, there is not enough papers dealing with the topic of risk management in agricultural production and in particular the risk management under climate changes. With this in mind as a goal of the paper we have determined the need to emphasize the importance and forms of agricultural production risks under climate changes. In an effort to achieve the goal, in this paper we first point to the basic characteristics of managing production risk in agriculture and then we point on the application of preventive measures, the role of the state as well as the comparative role of insurance. Considering that the impact of climate change has strong negative impact on insurance companies, we consider the issue of mandatory or voluntary conclusion of agriculture insurance contracts.

\section{Methodology and data sources}

Our research is focused on the analysis of the climate changes implications on production risk of agricultural production and measures that are available for the management of production risk (Galjak, Bojković, 2015). We use statistical analysis for data processing, analysing, presenting and comparing methods of management of production risks in agriculture production.

We compare foreign theorethical knowledge and empirical evidence with the same in Serbia 
in order to determine similarities and differenies in agriculture production risk management. We analyse the application of preventive measures in agriculture production risk management in order to determine what is done and what is neded to be done, on the basis of foreign experiences, to improve the prevention measures. As prevention is the key measure that is applied on field, this analyisis is particularly important and is basis for the analysis of the financial indemnification measures.

Financial indemnification can be provided by farmers themselves, the state and by insurance companies. We firstly analyse and compare the role of the state in production risk management in agriculture. This analyisis is done in order to compare domestic with foreign experiences.

Secondly, we analyse the insurance industry role in financing the consequences of risks. Insurance industry has a pivotal role in supporting agricultural production with reduction of fear of losses that could appear after loss events, by realisation of risks. Using combined data we compare the development of insurance of production risk in agriculture in Brazil, Russia, Indica, China, South African Republic, developing countries, USA and the world. We also compare agriculture insurance in the region of former Yugoslavia among Montenegro, Croatia, Macedonia, Slovenia and Serbia in 2011. Also, we conducted detailed analysis of the agriculture insurance industry in the region. We compare agriculture insurance in Montenegro, Croatia, Macedonia, Slovenia and Serbia for the period 2004-2011 using following data: crop and livestock insurance data denominated in EUR and their growth rates.

Finally, we analize the state of the agricultural insurance under the conditions of climate changes. As climate changes are the cause of more freqauent agricultural production risks, agricultural insurance is at the forefront of climate changes and thus it is indangerd regarding the level of capital and the ratio of premiums against losses. The solutions could be found in making agriculture insurance an obligatory. Thus, we compare foreign evidence of the success of measures concerning the dilema of obligingness or voluntairiness of agricultural insurance in order to provide conclusions and proposals for eventual application of obligingness of agricultural insurance in Serbia.

Data are gathered from verious trustfull sources. We use sources of various leading scientists in the field of agricultural economics, risk management and insurance. We base our conclusions on data from Organisation for Economic Co-operation and Development, Vode Vojvodine, national insurance associations, insurance agencies and National bank of Serbia.

\section{Management of production risk in agriculture}

In general, human beings do not have a tendency to risk and prefer a sure thing than the uncertain levels of consumption (Samjuelson, Nordhaus, 2009): people prefer outcomes with less uncertainty and with the same average values. Although most people have an aversion to risk, bearing in mind the theory of diminishing marginal utility, a reasonable reaction to the risk exposure does not necessarily always mean his avoiding only consideration while making decisions. In fact, one of the general economic principles suggest that the yields and the risk are mutually conditioned. All the decisions that people make which may have financial consequences is consisted of two key elements - time and risk. Greater risk may 
lead to an increase in profit of agricultural producers. If pursued complete avoidance of risk, agricultural production would not exist. For example, the decision on the selection of crops shall be made under conditions of uncertainty and represents a conscious acceptance of a risk, given that the result of speculation about the likely future outcome of and represents a choice between a large number of alternative relations risk / yield.

While there are many definitions of the risk management concept, the most appropriate determination, given the conciseness and comprehensiveness, we consider the following: risk management represents coordinated activities of the management and control of the organization in terms of risk (ISO, 2002). Risk management is a discipline which is an organized way to manage uncertainty based on information in the past and planning the possible alternative in future in order to make better, the information-based decisions. The main objective of risk management is to increase the probability of success and reduce the probability of failure and the uncertainty of achieving the objectives in agricultural production.

Risk management is based on implementation of gradual, logical steps that are standardized and are always applied. After we have determined strategy and risk tolerance coordinated with that strategy than we approach to risk assessment, which includes risk identification, quantification or establishing quantitative and qualitative assessment of the probability distribution, consequences and the time frame of achieving certain outcomes and finally prioritization and ranking in terms of probability and potential impact. A key step in risk management process, which is often equated to the very concept of risk management, refers to the treatment of risk, which essentially involves two options, control and risk financing. In the risk management in agriculture this step involves the use of an optimal combination of different forms of dealing with risk. For example, agricultural producer may decide to avoid risk by waiver of sowing of certain crops. He may reduce the risk of disease by vaccination of livestock. Also, the agricultural producer may decide to form a special reserve funds in case of major damage or may decide to transfer the part of the risk to the capital market or insurance. The application of some form of risk management is limited to their availability in a particular market.

\section{Preventive measures in agriculture risk management}

Preventive measures are measures that are applied in order to reduce the probability of adverse events. These measures represent a direct support to entrepreneurial activities in agricultural production. Often they are a reflection of the involvement in agriculture entrepreneurship. The preventive measures aimed at reducing the probability of production risks realization in agriculture include diversification, vertical integration and other preventive measures in livestock and crop production.

Diversification of risk to which agricultural producers are exposed can be accomplished in several ways. For example, it is possible to achieve spatial diversification (carrying out production in different locations), diversification of production (growing different types of crops and animals), diversified business (which provides a reduction that depends on agriculture as the only source of income from the agricultural holding), diversification of 
income hiring out of agricultural farms and distribution of yields, cost and risk through cooperatives.

Vertical integration is a form of risk management that allows connection of multiple participants in the value chain of agricultural production. For example, it is possible to connect the livestock farm with food manufacturers and / or wholesale. Vertical integration reduce the risks arising from variations in the quality or quantity of inputs or outputs. A similar function have sale contracts and production agreements. The sale contracts of agricultural products are contracts between farmers and buyers that must be concluded before products can be sold, where the farmer retains manufacturing risk but price risk is transferred in full, if there is a fixed price, or partially, if the sale is determined by future prices. Production contracts provide to buyers significant rights to control agricultural production and provide to agricultural producer reduction of price and production risk, given that these contracts specify production inputs that can be used, the quality and quantity of the product and the price which the buyer will pay.

In livestock production preventive measures are directed towards the protection of livestock health and early treatment of sick cattle. All measures can be divided into (DDOR, 1996): 1) zoohygienic (including ordinary measures such as the provision of adequate micro-climate and food, and emergency measures such as disinfection and disinfestation) 2) the veterinary (for example, vaccination, treatment of parasite diseases and similarly) and 3) zootechnical (including renewal of the heard, disposing of stunted animals and economic slaughter).

In crop production key production risks are conditioned by the weather and the most frequent are hail, frost, floods, fire and thunder. Preventive measures are applied for each risk and their specificity stems from the specificity of risks to which they are directed.

The construction of irrigation and drainage systems is of special importance in agricultural production. In Serbia there are great natural watercourses such as the Danube, Sava and Tisa. In Vojvodina, hydro system Danube-Tisa-Danube provides irrigation and drainage from the time of Maria Theresa. The construction of the Great Backa Canal in 1802 is considered the forerunner of the hydro system Danube-Tisa-Danube. Hydro system Danube-Tisa-Danube (DTD) connects the flows of rivers Danube and Tisa through Vojvodina and is a unique hydrotechnical system, whose primary purposes are: drainage, irrigation, water supply, acceptance of wastewater, sailing, accepting water from the territory of neighboring countries, forestry, fishing, tourism and recreation DTD drains a total of 1,060,000 ha of land including: Backa 550,000 ha and 510 ha of Banat. It is possible to irrigate from DTD 510,000 ha: in Backa $210,000 \mathrm{ha}\left(84 \mathrm{~m}^{3} / \mathrm{s}\right)$, and 300,000 ha in Banat $\left(120 \mathrm{~m}^{3} / \mathrm{s}\right)$. Length of navigable canals is 600.6 $\mathrm{km}$ : in Backa $355.5 \mathrm{~km}$ and $245.1 \mathrm{~km}$ in Banat (Vode Vojvodine, 2016). However, according to the percentage of irrigated land in relation to the total area of land suitable for irrigation, our country is far behind all neighboring countries and is at the bottom of Europe. Irrigation in the world is applied to slightly more than 1/6 of arable land and in Serbia is irrigated less than 1\% (Vode Vojvodine, 2016). The constructed irrigation systems include only 180,000 hectares of which are in operation only 30000 ha. Droughts in 2012 as the floods in 2014 and 2016, inevitably showed that investment in irrigation and drainage systems cost considerably less. 
Rotation of crops with crop diversification is a measure of improving agricultural production. Special importance is under climate changes when all the negative effect that it solves are exaggerated. Rotation or shift of crops represent regular replacement one type of crop to another in the same production area. Rotation helps farmers to provide organically increasing nutrient and water retention in the soil. This contributes to the reduction of gas emission that cause the greenhouse effect and has a positive effect on reducing the effect of climate change. Improved soil structure improves drainage, which reduces the risks of flooding during floods and improves the water supply of the plants during the drought. Also, rotation prevents pests and diseases that have increased presence thanks to climate change, and also prevents reduction of land degradation and may result in the long term in higher yields and great profitability of agricultural production.

\section{The role of the state in risk management in agriculture}

In most countries in the case of the significant damage realization caused by floods, fires and other disasters that threaten the income of agricultural producers, state ultimately intervene directly with the funds from the budget. It should be noted that state intervention in the management of risk in agriculture is justified only when the risk management measures based on market principles, such as insurance or futures, are not applicable or do not exist. For example, in order to recover from consequences by Hurricane Xynthia, which in February 2010 caused significant damage to agricultural producers in France, state promised the direct support from the fund for natural disasters. Due the floods in Serbia in 2010, state intervened from budget funds.

In the case of direct intervention of the state on the occurrence of catastrophic events, which is not always desirable because it stifles the development of private insurance, priority should be given to the existence of public funds in case of catastrophic events realization rather than ad-hoc type of assistance that leads to a negative impact on the budget. Some states subsidize the expenses for premium insurance coverage to farmers from the budget. For example, in Serbia the state subsidizes $40 \%$ of the insurance premium. Research shows that the existence of state programs in crop insurance in developed and in developing countries can not survive without government subsidies and in most cases social benefits were not clear enough to justify the cost of budgetary funds (Skees, Hazell, Miranda, 1999).

The state can also occur in the role of so-called reinsurers as is the case in China, which is indirectly subsidizing and supporting the development of agriculture insurance. In OECD countries, the most common form of state intervention is to support market prices that provides stabilization of prices and reduces price risk on the domestic market of agricultural products, and it is established the correlation between the degree of support market prices and the development of a risk management form (OECD, 2009). For example, higher levels of support corresponds to the lower level of development of risk management measures and vice versa.

In addition to participation in the ex-post risk management strategies in agriculture state can provide risk management support to the efforts of farmers through investments in the 
construction of irrigation systems, flood protection, scientific research and the promotion of market mechanisms such as futures, forwards and insurance.

\section{Comparative analysis of the role of insurance}

Insurance provides protect to agricultural producers from the negative realization of production risks by financing harmful consequences. The agricultural insurance is a mechanism for financing the result of production risks realization. Insurance reduces the uncertainty of farmers and the need to create individual savings accounts or funds, given that the need for cash reserves is reduced (Raulston et al., 2010).

From the perspective of risk management, insurance represents the risk transfer technique from individuals and legal entities to the insurance companies that are professionally engaged in the business of risk management in exchange for a certain amount of premium (Milojević, Zekić, 2015). Viewed from the perspective of agricultural producers, in exchange for a certain amount of the fixed cost in the form of premiums, the insurance as a form of risk management provides protection from the significantly greater damage whose occurrence is uncertain and is foreseen in conditions of the insurance contract. It enables to combine agricultural production risks such as damage to crops due to the hail or fire, theft of property of agricultural holdings, death or illness of animals and death or illness of agricultural producers.

Despite the great importance of insurance, variety of studies have shown conflicting results regarding the factors that have a positive impact on agricultural producers to conclude insurance contracts. The conclusion of the crop insurance contract has a positive effect on the level of business risk and the negative effect on the land ownership, income outside agricultural production and education (Velandia et al., 2009). However, farmers are more likely to conclude insurance if their perceived risk of the yield is increased, and if they are engaged in production on farms that are larger, older and that are not leased. Also, Enjolras and Sentis by analyzing agricultural insurance in France found that the size and financial strength of holdings, diversified production and catastrophic climatic events have a positive impact on farmers' decision on the conclusion of insurance (Sherrick et al., 2004).

Agricultural insurance has a different character in the world. Following the trends in the economy and society as well as in the overall trends in the insurance market, agriculture insurance is the most developed in developed countries. These trends are contrary to the relative importance that agricultural production has in these countries.

Despite the increasing importance of agriculture insurance in developing countries compared to developed countries and even with data on average in the world (see Table 1) it is recognized the under-representation of this type of insurance. 
Table 1. Comparative importance of agricultural insurance in developing countries, USA and the world in 2011

\begin{tabular}{|c|r|r|r|r|r|}
\hline & $\begin{array}{c}\text { \% agri. land } \\
\text { in total land }\end{array}$ & $\begin{array}{c}\text { Agricultur. } \\
\text { employment } \\
\text { in total } \\
\text { employment }\end{array}$ & $\begin{array}{c}\text { The share of } \\
\text { agriculture in } \\
\text { GDP }\end{array}$ & $\begin{array}{c}\text { Agri. insurance } \\
\text { premium in } \\
\text { USD millions }\end{array}$ & $\begin{array}{c}\text { Agricult. } \\
\text { insurance } \\
\text { preimum share } \\
\text { in GDP }\end{array}$ \\
\hline Brazil & 31,3 & 17 & 5,8 & 430 & 0,35 \\
\hline Russia & 13,2 & 9,7 & 4 & 552 & 0,98 \\
\hline India & 60,5 & 51,1 & 19 & 673 & 0,19 \\
\hline China & 56,2 & 39,6 & 10,1 & 2543 & 0,36 \\
\hline $\begin{array}{c}\text { South African } \\
\text { Republic }\end{array}$ & 81,7 & 5,1 & 2,5 & 153 & 1,77 \\
\hline $\begin{array}{c}\text { Developing } \\
\text { countries, total }\end{array}$ & n.p. & n.p. & n.p. & 5176 & 0,23 \\
\hline USA & n.p. & n.p. & n.p. & 11400 & 7,15 \\
\hline World & n.p. & n.p. & n.p. & 23511 & 0,83 \\
\hline
\end{tabular}

Source: Kalra, Xing, 2013.

While insurance agriculture premiums in the United States in 2011 amounted over \$ 11 billion, total premiums in this insurance in all developing countries amounted to just over $\$$ 5 billion, with nearly half achieved in China (over 2.5 billion). The same is the situation with the penetration indicator of agriculture insurance, which in this case represents the ratio of insurance agricultural premiums / share of agriculture in GDP (gross domestic product). While in the United States this indicator is over $7 \%$ in developing countries on average 0.23 and from leading developing countries, Brazil, Russia, India, China and South Africa, the biggest indicator is expressed in the case of South Africa. The results are even worse when Serbia and other countries in the region of the former Yugoslavia are observed (see Table 2 and 3).

Table 2. Comparative importance of agricultural insurance in countries of ex Yugoslavia in 2011

\begin{tabular}{|c|c|c|c|c|c|c|}
\hline Country & $\begin{array}{c}\text { Number of } \\
\text { policies }\end{array}$ & $\begin{array}{l}\text { Number of } \\
\text { farms }\end{array}$ & $\begin{array}{l}\text { Number of } \\
\text { farms from } \\
\text { year }\end{array}$ & $\begin{array}{l}\text { Agricultural } \\
\text { insurance } \\
\text { premium } \\
\text { (in EUR) }\end{array}$ & $\begin{array}{l}\text { Agricul. } \\
\text { insuran. } \\
\text { prem. per } \\
\text { farm (in } \\
\text { EUR) }\end{array}$ & $\begin{array}{l}\text { Number of } \\
\text { policies / } \\
\text { Number of } \\
\text { farms }\end{array}$ \\
\hline Montenegro & 38 & 48870 & 2010 & 69465,85 & 1,42 & $0,08 \%$ \\
\hline Croatia & 21056 & 232328 & 2010 & 27375203,02 & 117,83 & $9,06 \%$ \\
\hline Macedonia & 438 & 192378 & 2007 & 442381,5625 & 2,30 & $0,23 \%$ \\
\hline Slovenia & 38310 & 74711 & 2010 & 14633954 & 195,87 & $51,28 \%$ \\
\hline \multirow[b]{2}{*}{ Serbia } & \multirow[b]{2}{*}{13035} & 778891 & 2002 & \multirow[b]{2}{*}{11832142,12} & 15,19 & $1,67 \%$ \\
\hline & & 452606 & 2011 & & 26,14 & $2,88 \%$ \\
\hline
\end{tabular}

Source: authors' calculations on data gathered from national insurance associations, insurance agencies and National bank of Serbia 


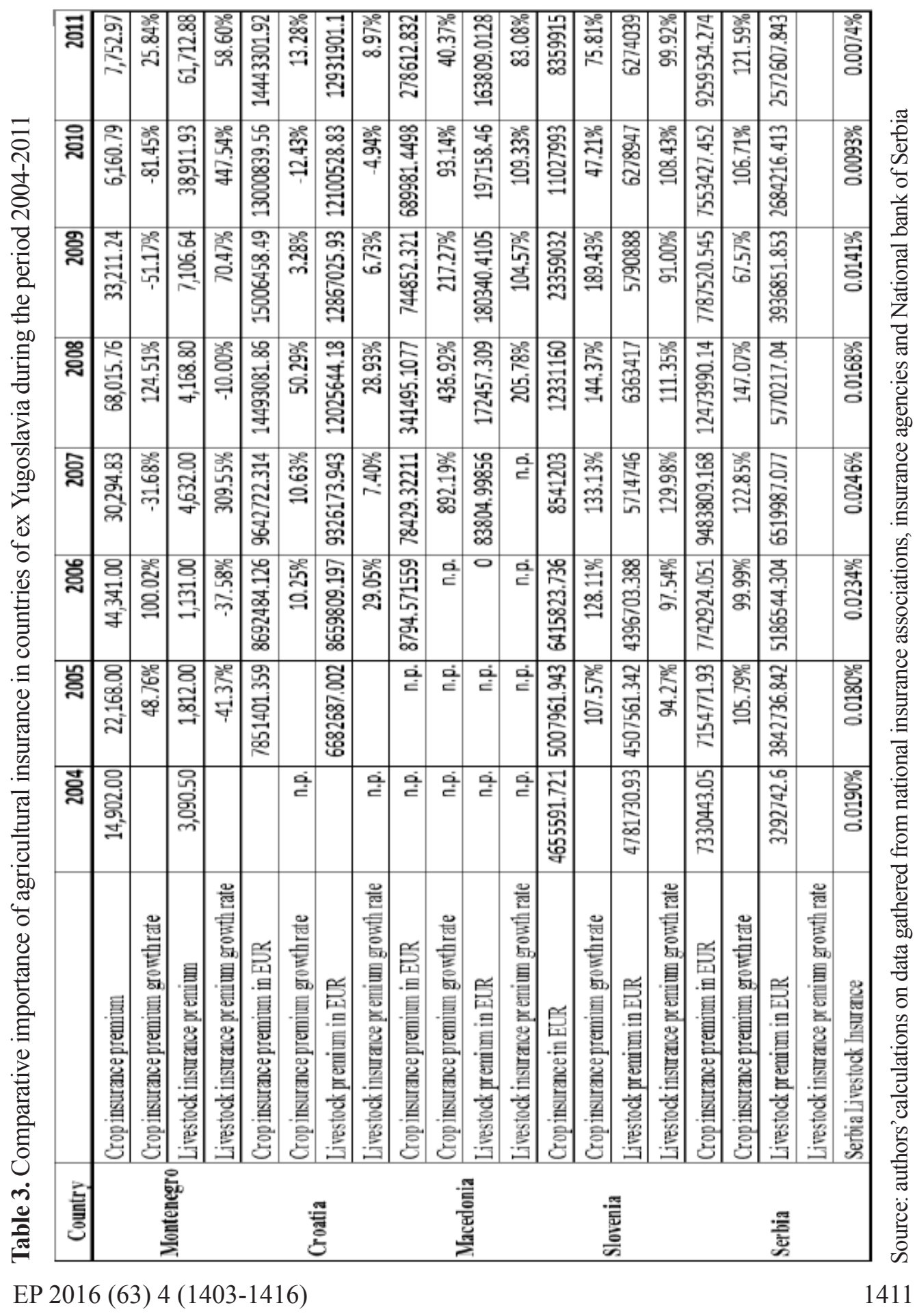


In all countries of the region, with the exception of Slovenia, there is a low total volume of insurance agricultural premiums whose share both in the total insurance premium, as well as to the farm is extremely low. The worst condition is present in Montenegro and Macedonia, where the premium per farm is 1.42 euros, or 2.30 euros. Ratio of the number of polices and the number of farms in these two countries indicates that only $0,08 \%$ and $0,23 \%$ of farms are insured. Agricultural insurance is the most developed in Slovenia, where the premium per farm amounted to 195.87 euros and over half of agricultural holdings was insured. In Croatia, the amount of premium per farm was relatively close to the amount of premiums in Slovenia, and amounted to 117.83 euros but $9.06 \%$ of all the agricultural holdings was insured.

Data for Serbia vary depending on whether the data of the number of farms is used from the census in 2002, when the total numbers of households accounted for 778,891 or if is used the data from 2011 when the number of farms registered in the Register of agricultural households, or 452,606 households, whereby the actual number of households is much higher. If is used data from 2002, the amount of premiums per farm is 15.19 euros and only $1.67 \%$ of all households are insured. Data used from 2011 show that the premium per farm amounts to 16.14 euros with $2,88 \%$ of all agricultural holdings insured. Those comparative data explicitly show that agricultural insurance in developed countries is very important, but according to the indicator of significance of the agricultural sector, in developing countries, especially in the countries of the region, their participation should be higher.

\section{Obligingness or voluntariness of agriculture insurance under climate changes}

Increased manifestation of adverse events with all the disastrous consequences is inherent characteristic of today's world that is characterised by high globalization and evident manifestation of climate change. Catastrophic risk are charaterized by so-called accumulation, or culmination of risks from multiple branches of insurance in which the risks are positively correlated with each other, and often affect a broad geographical area, which restricts limiting riks trough diversification. In the context of realization of the catastrophic damage while having in mind the crucial importance of insurance and reinsurance, and the need for a changed role of the state, there is the tendency to certain types of insurance coverage as compulsory (Njegomir, 2015).

One of the basic principles of private insurance implementation, or providing insurance coverage by insurance companies, is voluntarily conclusion of insurance contracts. Depending on individual risk tolerance and the willingness to accept the risk and to self-finance the consequences of the realization of that risk depends on the existence of demand for insurance services and establishment of relations between applicant of insurance service and insurance companies.

The specificity of the insurance market is the fact that relations between participants on the insurance market can be established as a result of laws and contracts. Concluding contracts on various types of loans borrowers can commit to the conclusion of a credit insurance, and in certain cases, the risk life insurance. For certain types of insurance law may establish the obligation of concluding the contract. It is common practice in the world that there is a 
regulatory definition of obligatory conclusion of certain types of liability insurance, the most common automobile liability insurance, but there are cases where the mandatory conclusion is certain for other types of insurance (for example, insurance against the risk of fire is compulsory in Argentina and South Korea). However, despite mandatory conclusion of this type of insurance, no insurance company has monopoly to conclude such contract, which in this area allows maximum competition between insurance companies.

One of the problems faced by developing countries, including countries in the region and Serbia, is the lack of representation of private insurance, especially when it comes to the insurance of agriculture. The problem lies in the fact that individuals based on the previous experience expect that the state will cover the cost of catastrophic losses. On the other hand, it often happens that at the state level prevail awareness of funding opportunities from international sources, or cover the budget deficit with foreign donations. Given the above and the fact of insufficient demand for agricultural insurance in Serbia, there is a question of needs and possibilities to introduce mandatory this of type insurance.

In some developing countries there is obligation of concluding the agriculture insurance. In India and the Philippines, there is a mandatory crop insurance for farmers who are in the process of granting loans from banks. The same situation is present in Brazil, where farmers are obligated to conclude crop insurance if they want to obtain loans from state banks (Kalra, Xing, 2013).

The existence of compulsory conclusion of agricultural insurance, as in the cases where the obligation is associated with obtaining loans has more benefits. Compulsory insurance can serve as collateral but also to improve awareness of the importance of agriculture insurance and to avoid the impact of adverse selection through a broader participation of farmers in the conclusion of insurance contracts. Compulsory insurance in agriculture can reduce distribution and transaction costs that are typical for this type of insurance (Njegomir, 2007).

Compulsory insurance has negative implications because the insured feel that is insurance imposed on them rather than to see the need for adequate insurance protection from risk by themselves. In some countries, such as Romania, the introduction of compulsory insurance in the domain of catastrophic risk insurance has not given positive results. We also believe that in the domestic front it would be the best to promote awareness through education of farmers about the need for the conclusion of insurance, especially in terms of climate change realization. Improving awareness, we are convinced, would give significantly better results in the national levels.

\section{Conclusion}

Exposure of agricultural production to agricultural production risk increases with climate change, which emphasizes the importance of managing this risk. Risk management, based on information from the past, attempts to reduce the overall level of production risk that farmers are affected by. Farmers reduce the probability of failure with management of production risk.

Manufacturing risks are managed by application of preventive measures and also by 
financing the result of the risk realization. Preventive measures that are commonly used include diversification, vertical integration, irrigation and drainage, crop rotation and other measures. Financing the result of production risks realization can be and is mostly achieved through the intervention of the state and insurance.

Government intervention is often inadequate used through direct financing of the harmful consequences of risk realization. The right way of government intervention is trough subsidizing insurance agriculture premiums. Government intervention is only justified in cases where private mechanisms, including private insurance, fail and does not provide protection for farmers.

An important place in the protection of farmers belongs to insurance that provides indirect economic protection for damages to agricultural producers that arise from the realization of production risk. Despite the great importance of insurance, a demand for concluding agriculture insurance contract varies in the world and it is evident that it is contrary to the importance that agriculture has. In fact, it is small in developing countries and large in developed countries. In the countries in the region, insurance agriculture premiums are particularly small so as average premium per farm. Under such conditions and with parallel great exposure of insurers to negative effects of climate change there is a frequently asked question of compulsory insurance. Obligation is justified by possibility of even dispersion of risk by increasing the number of insured as well as the broader social interest. However, experience in the application of obligingness are different. Based on the research results, we believe that in Serbia the introduction of mandatory agricultural insurance would give the best results. Much better solution would be education of farmers to improve awareness of the possibilities and importance of agriculture insurance.

\section{References}

1. DDOR (1996): Priručnik za praksu u osiguranju i reosiguranju. DDOR, Novi Sad.

2. Gramig, B., Barnett, B.J., Skees, J.R., Black, J.R. (2006): Incentive compatibility in risk management of contagious livestock diseases. In S.R. Koontz, D.L. Hoag, Thilmany, D.D., Green, J.W., Grannis J.L. (2006): The Economics of Livestock Disease Insurance: Concepts, Issues and International Case Studies, CABI Publishing, Cambridge.

3. ISO (2002): ISO/IEC Guide 73:2002 Risk management. Vocabulary. Guidelines for use in standards, International Organization for Standardization, Geneva.

4. Galjak, I., Bojković, Č. (2015): Istorijski aspekti razvoja tržišta kapitala i korporativnog upravljanja, Oditor, Belgrade, Serbia, no. 10, pp. 10-16.

5. Kalra, A., Xing, L. (2013): Partnering for food security in emerging markets. Sigma No 1/2013, Swiss Re, Zurich.

6. Milojević, I., Zekić, M. (2015): Organizaciona struktura preduzeća kao pretpostavka konsolidacije bilansa, Oditor, Belgrade, Serbia, no. 12, pp. 22-28.

7. Njegomir, V. (2007): Kanali distribucije usluga osiguranja i reosiguranja. Marketing, vol. 38 , no. 1-2, pp. 47-53. 
8. Njegomir, V. (2015): Obaveznost osiguranja. Svet osiguranja, vol. 5, no. 5.

9. OECD (2000): Income Risk Management in Agriculture. OECD Publishing, Paris.

10. OECD (2009): Managing Risk in Agriculture: A Hollistic Aproach. OECD Publishing, Paris.

11. Pejanović, R., and Njegomir, V. (2011): Problemi upravljanja rizicima u poljoprivredi. Ekonomika poljoprivrede, vol. 58, no. 1, pp. 91-103.

12. Raulston, J.M., Richardson, J:W., Outlaw, J.L., and Knapek, G.M. (2010): Does Crop Insurance Reduce the Need for Cash Reserves in Savings Accounts? Paper presented at the SAEA Annual Meeting, Orlando, FL, February 6-9.

13. Samjuelson, P.A., and Nordhaus, V.D. (2009): Ekonomija. Mate, Beograd.

14. Shaik, S., Barnett, B.J., Coble, K.H., Miller, J.C. and Hanson, T. (2006): Insurability conditions and livestock disease insurance. In S.R. Koontz, D.L. Hoag, D.D. Thilmany, J.W. Green, and J.L. Grannis (eds.), The Economics of Livestock Disease Insurance: Concepts, Issues and International Case Studies, CABI Publishing, Cambridge.

15. Sherrick, B.J., Barry, P.J., Ellinger, P.N., and Schnitkey, G.D. (2004): Factors Influencing Farmers' Crop Insurance Decisions. American Journal of Agricultural Economics, vol. 86, no. 1, pp. 103-114.

16. Skees, J., Hazell, P., and Miranda, M. (1999): New Approaches to Crop Yield Insurance in Developing Countries. EPTD Discussion Paper 55, International Food Policy Research Institute, Washington, D.C.

17. Snow, A.A., Andow, D.A., Gepts. P., Hallerman, E.M., Power, A., Tiedje, J.M., and Wolfenbarger, L.L. (2005): Genetically engineered organisms and the environment: Current status and recommendations. Ecological Aplications, vol. 5, no. 2, pp. 377-404

18. Velandia, M., Rejesus, R.M., Knight, T.O., and Sherrick, B.J. (2009): Factors Affecting Farmers' Utilization of Agricultural Risk Management Tools: The Case of Crop Insurance, Forward Contracting, and Spreading Sales. Journal of Agricultural and Applied Economics, vol. 41, no. 1, pp. 107-123.

19. Vode Vojvodine (2016): Hidrosistem Dunav-Tisa-Dunav, Javno vodoprivredno preduzeće ,Vode Vojvodine”,http:/www.vodevojvodine.com/Category/CategoryPages/ 4?title $=\%$ D0 $\%$ A5\%D1\%81 \%D0\%94\%D0\%A2\%D0\%94 (accessed 25.07.2016.) 


\title{
UPRAVLJANJE RIZICIMA U POLJOPRIVREDI U USLOVIMA KLIMATSKIH PROMENA
}

\author{
Vladimir Njegomir, ${ }^{4}$ Rajko Tepavac, ${ }^{5}$ Tamara Bikicki ${ }^{6}$
}

\begin{abstract}
Rezime
Poljoprivredna proizvodnja izložena je dejstvu različitih rizika od kojih proizvodni rizici predstavljaju njenu specifičnost, s obzirom da proizilaze iz činjenice obavljanja proizvodnje na otvorenom i upravljanja živim bićima. Klimatske promene direktno utiču na proizvodne rizike poljoprivredne proizvodnje. U literaturi se klimatske promene relatvino dovoljno istražuju ali ne postoji dovoljno istraživanja koja se bave tematikom upravljanja rizicima u poljoprivrednoj proizvodnji a posebno upravljanja rizicima u uslovima ostvarenja klimatskih promena. Imajući to u vidu za cilj rada smo odredili potrebu da ukažemo na značaj i oblike upravljanja rizicima $u$ poljoprivrednoj proizvodnji u uslovima klimatskih promena. $U$ nastojanju da cilj ostvarimo u radu prvo ukazujemo na osnovne karakteristike upravljanja proizvodnim rizikom u poljoprivredi a potom ukazujemo na primenu preventivnih mera, ulogu države kao i komparativnu ulogu osiguranja. S obzirom da uticaj klimatskih promena snažno negativno utiče na osiguravajuća društva koja osiguravaju poljoprivredne rizike, razmatramo i problematiku da li zaključivanje ugovora o osiguranju poljoprivrede treba biti obavezno ili dobrovoljno.
\end{abstract}

Ključne reči: poljoprivreda, rizici, upravljanje, prevencija, država, osiguranje.

4 Vanredni profesor, dr Vladimir Njegomir, Fakultet za pravne i poslovne studije dr Lazar Vrkatić, Bulevar oslobođenja br. 76, 21000 Novi Sad, Telefon: +381 6413930 05, E-mail: vnjegomir@eunet.rs

5 Vanredni profesor, dr Rajko Tepavac, Institut za ekonomiku i finansije, Bulevar Mihajla Pupina br. 10 B/I, 11000 Beograd, Telefon: +381 63600 217, E-mail: tepavac57@gmail.com

6 Tamara Bikicki, MSc, Triglav osiguranje, Milutina Milankovića br. 7a, 11000 Beograd, Telefon: +3816388785 14, E-mail: tamarabikicki@gmail.com 